\title{
MEMBUMIKAN KONSEP ETIKA ISLAM ABDURRAHMAN WAHID DALAM MENGATASI PROBLEMATIKA KELOMPOK MINORITAS DI INDONESIA
}

\author{
Muhammad Mahfud \\ Sekolah Tinggi Agama Islam al-Azhar Menganti Gresik, Indonesia \\ E-mail: mahfudmuhammad90@yahoo.co.id
}

\begin{abstract}
Abdurrahman Wahid was one of the pioneers realization of Islamic ethical values, although it was believed to be counterproductive. He has transformative thinking in interpreting Islamic teachings especially promoting Islamic social ethics. There are three main driving factors dominating minorities; misunderstanding of Indonesia which is a democratic country, the essence of the values of Islamic teachings, and not yet understanding the importance of awareness of grounding Islamic ethics that is transformed into the social realm. Form of minority domination in Indonesia, among others; violence experienced by minority groups in Sampang who are Syi'ah who are considered to damage the majority of Islamic teachings, and others. There are three strategies to ground Islamic ethics in order to overcome the problems of minorities in Indonesia; transformation of Islamic ethical values in the social domain; the implementation of Islamic ethical values in overcoming the problems of minority groups, the value of love for peace, the value of upholding justice, the value of equality of human position in the eyes of law and the state, and the value of social care, and the orientation of the development of Islamic ethics must be directed towards the welfare of the people.
\end{abstract}

Keywords: Islamic Ethics, Minority Groups, Indonesia

\section{Pendahuluan}

Secara substansial, Islam mempunyai peranan yang sangat penting dalam pembangunan kehidupan umat manusia. Sebagai sistem nilai (tauhid, syariah, akhlak), Islam seharusnya dapat dipahami dan diamalkan sekaligus oleh setiap anggota masyarakat sehari-hari dalam menjalankan kehidupan berbangsa dan bernegara. Untuk memahami ajaran Islam sebagai sumber etik, perlu mengedepankan kesejahteraan sosial (almașlạ̣ah al-'âmmah) dengan implementasi nilai-nilai ajaran agama yang 
mencakup etika individual dan sosial. Sedangkan untuk mengamalkan ajaran Islam sebagai agama yang raḥmatan li al-álamîn, perlu transformasi nilai-nilai Islam ke dalam ranah sosial yakni dari yang berorientasi meraih identitas lahiriah dalam melaksanakan ritual-ritual keagamaansecara ideal menuju Islam yang juga berfungsi untuk penyelamatan individu dan menyelesaikan problematika sosial.

Kondisi di atas merupakan hal-hal yang ideal bagi umat Islam,namun pada kenyataannya, tidak selaras dengan substansi Islam sebagai panduan universal dalam tindakan moral. Islam yang semula hadir ke dalam sebuah masyarakat melalui prinsip-prinsip kebaikan moral, seperti keadilan, kejujuran, dan persamaan, justru berubah menjadi Islam yang terkesan tidak beretika dalam mengatasi berbagai problem sosial yang ada dalam masyarakat. Mayoritas umat Islam, khususnya masyarakat awam hanya meyakini pentingnya hal-hal yang terkait etika individual, belum menjamah pentingnya etika sosial. Ini terbukti dengan banyaknya umat Islam yang melakukan tindakan anarkis atas nama Islam seperti terorisme, tidak mengedepankan toleransi dalam perbedaan ideologi beragama sesama umat Islam, juga perbedaan SARA dalam kehidupan sosial, dan tidak peduli nasib kelompok minoritas di lingkungan sekitar.

Beberapa problematika sosial tersebut membuktikan telah memudarnya etika umat Islam sebagai bagian dari warga negara Indonesia yang dahulu dikenal sebagai bangsa yang cinta damai, ramah, toleran, dan beradab. Hal ini disebabkan rendahnya kualitas pemahaman dan pengamalan masyarakat terhadap ajaran-ajaran moral agamanya. Loyalitas terhadap kelompok ideologi tertentu mendorong untuk saling unggul sehingga seringkali tidak sadar mereka mengorbankan kelompok minoritas yang tidak bersalah. Selain itu, keinginan untuk mewujudkan cita-cita negara Islam menjadikan trauma dan ketakutan bagi kelompok masyarakat muslim dan non muslim di Indonesia yang cinta damai. Atas dasar inilah, perlu membumikan nilai-nilai etika Islam yang berorientasi pada kepentingan sosial.

Abdurrahman Wahid bisa dikatakan salah satu pionir bagi perwujudan nilai-nilai itu meski diyakini bersifat kontra-produktif terhadap upaya menegakkan prinsip-prinsip demokrasi, HAM dan pluralisme di kawasan yang majemuk ini. Beliau memiliki pemikiran transformatif dalammemaknai ajaran islam terutama dalam hal etika sosial. Ia meletakkan Islam sebagai sumber etik untuk menyelesaikan problem dalam berbagai bidang kehidupan berbangsa dan bernegara. Ia menerapkan konsep Islam yang mulanya oleh beberapa kelompok umat islam sebagai suplemen bagi Negara akhirnya menjadi komplemen agar 
tidak menjadikan Islam sebagai simbol-simbol agama sebagai legitimasi bagi kekuasaan. Betapa berharganya pemikiran Abdurrahman Wahid tentang konsep etika Islam yang ditransformasi ke dalam konteks sosial kebangsaan mendorong penulis untuk menelaah pemikiran Abdurrahman Wahid.

\section{Problematika Kelompok Minoritas di Indonesia}

Suatu masyarakat terdiri atas kelompok-kelompok manusia yang saling terkait oleh sistem-sistem, adat istiadat, ritus-ritus serta hukumhukum khas dan yang hidup bersama. Kehidupan bersama ialah kehidupan yang di dalamnya kelompok-kelompok manusia hidup bersama-sama di suatu wilayah tertentu dan sama-sama berbagi iklim serta makanan yang sama. ${ }^{1}$ Masyarakat terdiri dari beberapa badan dan organisasi primer serta sekunder. Badan-badan ini, serta individuindividu yang terkait dengan mereka, semuanya saling berhubungan erat. Perubahan-perubahan apapun pada salah satu lembaga ini, baik bersifat kebudayaan, keagamaan, keekonomian, kehukuman atau kependidikan membawa perubahan pada lembaga-lembaga lainnya. Dengan demikian, kehidupan bermasyarakat merupakan sebuah gejala yang bergantung pada mesin masyarakat. ${ }^{2}$

Masyarakat terbagi menjadi kelompok-kelompok, lapisan-lapisan dan kelas-kelas berlainan, yang kadang-kadang saling bertentangan. Ada kelompok penguasa dan terkuasai, kelompok mayoritas dan kelompok minoritas, kelompok kuat dan kelompok lemah. Menurut penafsiran sebagian orang bahwa dalam al Quran, kekafiran, kemunafikan, kesyirikan, kebobrokan moral serta para tiran kebanyakan berasal dari kelompok-kelompok yang dinamakan mutraf (yang berkelimpahan), musrif (yang berlebihan), mala' (penguasa), muluk (raja-raja), mustakbir (yang pongah) dan seterusnya. Sedangkan ketaqwaan, kejujuran, keluhuran moral kebanyakan berasal dari kelompok-kelompok yang dinamakan para nabi (anbiya') dan rasul, para pemimpin (aimmah), para pemegang kebenaran (siddiqun), dan seterusnya muncul dari kelompok tertindas dan lemah. ${ }^{3}$

Kedudukan suatu kelas, entah sebagai kelas mayoritas atau minoritas merupakan dasar dan pondasi bukan saja bagi semua sikap, kesetiaan dan kecenderungan manusia, tetapi juga bagi semua gejala serta perwujudan budaya dan masyarakat. Kelas mayoritas, karena menguasai hak-hak

\footnotetext{
${ }^{1}$ Murtadha Muthahhari, Masyarakat dan Sejarah (Bandung: Mizan, 1985), 15.

2 Murtadha Muthahhari, Masyarakat dan Sejarah, 21.

${ }^{3}$ Murtadha Muthahhari, Masyarakat dan Sejarah, 40-41
} 
istimewa masyarakat, merupakan para obskuran, tradisionalis dan berlindung di bawah konservatisme, sedang kelas minoritas berpandangan maju, anti tradisionalis, progresif, bersemangat, aktif, dan selalu berada di barisan depan revolusi. Kesetiaan kepada suatu kelas tertentu merupakan ukuran semua hal bagi yang menganut teori ini. ${ }^{4}$

Menurut penulis, kelompok mayoritas ialah kelompok yang dari segi jumlahnya lebih banyak dan dari segi peran dan kedudukannya lebih unggul daripada kelompok yang lain. Sedangkan kelompok minoritas ialah kelompok yang dari segi jumlahnya lebih sedikit dan dari segi peran dan kedudukannya lebih rendah (termarjinalkan) daripada kelompok yang lain. Dengan kata lain dikatakan kelompok mayoritas ialah kelompok yang mendominasi (kuat) dan kelompok minoritas ialah kelompok yang terdominasi (lemah). Namun, sebenarnya dalam kehidupan demokrasi dua kutub kelompok ini tidak perlu ada karena demokrasi menjunjung tinggi persamaan hak, peran, dan kedudukan sebagai warga masyarakat.

Pada realitanya, idealitas prinsip demokrasi tidak selaras dengan kondisi di masyarakat di masa kini. Banyak hal yang bertentangan dengan prinsip demokrasi justru dilakukan seperti tindak anarkis termasuk terorisme $e^{5}$, konflik antar anggota masyarakat dengan senjata tajam, dan lain-lain yang tidak beretika. Dalam hal ini yang sering dikorbankan ialah kelompok minoritas sehingga terkadang identik dengan penindasan. Padahal merekalah yang sebenarnya harus dibela dengan berbagai pertimbangan demokratis berdasarkan etika sosial tanpa melihat perbedaan SARA.

Banyak problematika kelompok minoritas di Indonesia. Berdasarkan analisis penulis, diantara faktor yang mendorong adanya kelompok mayoritas yang mendominasi kelompok minoritas sehingga merasa tertindas dan termarjinalkan ialah: (a) belum memahami bahwa Indonesia merupakan negara demokrasi, bukan negara Islam sehingga semua orang

\footnotetext{
${ }_{4}^{4}$ Murtadha Muthahhari, Masyarakat dan Sejarah, 44

5 Tentang terorisme, Abdurrahman Wahid memiliki dua pandangan dalam mendudukkan persoalan ini. Pertama, pandangan para teroris bukan pandangan umat Islam. Itu pandangan sejumlah orang yang salah bersikap melihat aneka tantangan yang dihadapi ajaran agama Islam. Kedua, pandangan itu sendiri bukan pendapat mayoritas. Selain itu, terjadi kesalahan pandangan, hubungan antara agama dan kekuasaan akan menguntungkan agama. Padahal jelas, dari proses itu sebuah agama akan menjadi alat pengukuh dan pemelihara kekuasaan. Jika sudah demikian, agama akan kehilangan peran lebih besar, yaitu inspirasi bagi pengembangan kemanusiaan. Selain itu, mengurangi efektivitas peran agama sebagai pembawa kesejahteraan. Lihat Abdurrahman Wahid. Islamku, Islam Anda, Islam Kita (Jakarta: Wahid Institute, 2006), 21.
} 
Indonesia yang dikenal berbeda-beda secara agama, keyakinan, etnis, bahasa, dan warna kulit, memiliki persamaan hak, peran dan kedudukan sebagai warga negara, (b) belum memahami esensi nilai-nilai ajaran Islam yang juga berorientasi pada perwujudan kesejahteraan sosial, dan (c) belum memahami pentingnya kesadaran membumikan etika Islam yang ditansformasikan ke dalam ranah sosial.

Ada beberapa bentuk dominasi terhadap kelompok minoritas di Indonesia, yakni: (a) kekerasan yang dialami kelompok minoritas di Sampang yang berpaham Syi'ah karena dianggap berbeda ideologi dengan kelompok mayoritas di sana selain dianggap sebagai kelompok yang mengancam keutuhan umat Islam, (b) menomorduakan kelompok minoritas warga Tionghoa yang dianggap warga keturunan sehingga seringkali tidak diberi ruang gerak di bidang publik khususnya pemerintahan, (c) kecaman terhadap kelompok minoritas umat Islam seperti Ulil Abshar Abdalla karena perbedaan ideologi pemikiran Islam melalui liberalisme Islam yang dianggap bisa meruntuhkan asas-asas keyakinan sendiri akan kebenaran Islam, (d) memusuhi dan membatasi ruang gerak orang-orang mantan Napol dan Tapol PKI yang kebanyakan bukan orang yang benar-benar memahami ideologi komunis, dan (e) kecaman terhadap aksi goyang ngebor Inul Daratista yang dipandang berbau pornografi sehingga seringkali dicekal oleh kelompok mayoritas yang kontroversi dengannya.

\section{Pentingnya Memaknai Indonesia Sebagai Negara Demokrasi, Bukan Negara Islam dalam Pandangan Abdurrahman Wahid}

Indonesia merupakan negara kesatuan yang mengedepankan prinsip demokrasi dengan ideologi Pancasila sebagai dasar negara. Namun, konsep demokrasi di Indonesia masih belum menemukan bentuknya yang mapan. Banyak perdebatan di kalangan akademisi hanya sebatas tentang apa dan bagaimana penerapan demokrasi. Meminjam istilah Gallie, demokrasi adalah essentially contested concept, sebuah konsep yang secara esensial diperebutkan pemaknaannya. Ketidakjelasan definisi demokrasi sebenarnya terkait dengan persoalan kejelasan identitas keindonesiaan. ${ }^{6}$

Indonesia yang multi etnik dan budaya apalagi mayoritas penduduknya beragama Islam merupakan problem yang harus dihadapi dalam mewujudkan negara yang demokratis. Namun, Indonesia hanya butuh waktu untuk berproses menuju demokrasi karena saat ini berada

6 Masdar Hilmy. Islam Profetik; Substansialisasi Nilai-nilai Agama dalam Ruang Publik (Yogyakarta: Kanisius, 2008), 76-77. 
dalam masa transisi dari pemerintahan otoriter ke pemerintahan demokratik. Meskipun era reformasi saat ini menawarkan kebebasan yang tidak pernah dialami sebelumnya sehingga banyak membawa dampak destruktif yang kompleks seperti terorisme, bebas berdemonstrasi yang seringkali dengan tindakan anarkis, konflik atas nama SARA, dan lain-lain.

Tentang demokrasi, Abdurrahman Wahid (Gus Dur) mengatakan bahwa demokrasi di Indonesia itu berkembang. Tidak ada yang bisa dibilang mana model demokrasi yang cocok dan layak karena demokrasi itu politik. Politik itu alat, seni mencapai hal yang dimungkinkan. Yang penting model apapun yang diterapkan, harus setia kepada cita-cita yang ideal. ${ }^{8}$ Hakikat demokrasi ialah cara untuk mengutarakan pendapat, keinginan, dan memperjuangkan kepentingan, sedangkan inti demokrasi adalah kontrol sosial. Kritik atas jalannya pemerintahan terhadap pihak yang memegang kekuasaan, oleh orang yang berada di luarnya. Kontroversi adalah bagian tak terpisahkan dari kehidupan demokrasi. ${ }^{9}$

Dari pengertian demokrasi menurut Gus Dur, kehidupan demokrasi sarat dengan cita-cita yang ideal, kontrol sosial, dan kontroversi. Seringkali beliau memaparkan bahwa kesejahteraan sosial (al-maslabah al'âmmah) harus dijunjung tinggi dan menjadi cita-cita yang ideal dari perjuangan mewujudkan demokrasi. Sistem demokrasi tidak boleh mementingkan kepentingan kelompok tertentu, membedakan posisi warga negara, memunculkan kelompok minoritas-mayoritas sehingga tidak memiliki kesamaan peran sekaligus posisi, juga tidak boleh memaksakan kehendak atau pendapat tanpa memberi kebebasan seseorang untuk berbicara dan berbuat.

Kontrol sosial dimaknai Gus Dur sebagai upaya melihat dan memberikan kritik atas jalannya pemerintahan. Sebagaimana pemahaman tentang pemerintahan demokratis ialah pemerintahan yang ditentukan otoritasnya oleh rakyat sebagai lawan dari sistem pemerintahan untuk

\footnotetext{
7 Harus dipahami bahwa makna demokratisasi bukan untuk menang-menangan, mementingkan kelompok atau kebebasan memisahkan diri dari bumi pertiwi, tetapi sebagai sarana bagi masyarakat untuk ikut ambil bagian dalam menata pemerintahan. Pengertian demokratisasi, selain terjaminnya peran serta masyarakat juga mengandung unsur kontrol, menyampaikan pendapat, berserikat, membentuk organisasi. Dalam penerapannya pemahaman ini hendaknya tidak terfokus pada pemikiran yang sempit tetapi pemikiran progresif yang mengutamakan kepentingan nusa dan bangsa. Lihat A. Hasyim Muzadi dan Benediktus Bosu. Menuju Indonesia Baru; Strategi Pemberantasan Tindak Pidana Korupsi (Malang: Bayumedia Publishing, 2004), 9.

8 Abdurrahman Wahid, Tabayun Gus Dur (Yogyakarta: LkiS, 1998), 112

${ }^{9}$ Abdurrahman Wahid, Tabayun Gus Dur, 192.
} 
satu orang (monarki) atau kelompok yang diistimewakan, sekaligus lawan dari pemerintahan tirani dan oligarki. ${ }^{10}$ Karena kita sebagai rakyat, maka kita berhak memberikan kritik terhadap proses berlangsungnya pemerintahan oleh pemegang kekuasaan yang tidak sesuai dengan citacita ideal demokrasi seperti tindakan korupsi, kolusi, dan nepotisme. Hal ini berarti pemerintah tidak mengutamakan kepentingan orang banyak, bahkan merugikan rakyat.

Karena demokrasi mengedepankan kebebasan berbicara, mengutarakan pendapat dan berekspresi, maka seringkali menuai berbagai kontroversi, baik dalam pendapat maupun sikap. Mengingat Indonesia memiliki beragam suku, agama, ras, budaya, dan golongangolongan tertentu dengan ideologi berbeda, maka kontroversi merupakan hal yang tidak bisa dihindari. Namun, semua bisa diatasi dengan menerapkan etika sosial Islam. Hal ini karena demokrasi tidak bertentangan dengan nilai-nilai Islam yang sejumlah orang berpendapat bahwa demokrasi serba berasal dari konsepsi Barat sehingga selamanya harus ditolak. Sebagaimana dipaparkan di atas bahwa Gus Dur sangat menjunjung tinggi prinsip demokrasi, namun dalam pelasanaannya tidak boleh bertentangan dengan nilai-nilai Islam sebagai etika sosial.

Tentang negara Islam, Gus Dur memberikan dua pendapat. Pertama, sebuah negara Islam harus ada seperti pendapat kaum elit politik di Saudi Arabia, Iran, Pakistan, dan Mauritania. Kedua, seperti dianut oleh NU dan ormas-ormas lainnya menyatakan tidak perlu ada negara Islam. Ini disebabkan oleh heterogenitas sangat tinggi di antara warga negara Indonesia, di samping kenyataan ajaran Islam menjadi tanggung jawab masyarakat, dan bukannya negara. Pandangan ini bertolak dari kenyataan bahwa Islam tidak memiliki ajaran formal yang baku tentang negara. ${ }^{11}$ Ajaran yang jelas ada adalah mengenai tanggung jawab setiap kaum muslim untuk melaksanakan Islam. Meski Gus Dur memaparkan dua pendapat tentang gagasan negara Islam, tapi menurutnya, Islam tidak memiliki konsep bagaimana negara harus dibuat dan dipertahankan. ${ }^{12}$

Indonesia terdiri dari masyarakat yang beragam, baik muslim maupun non muslim. Jika negara Islam tetap ingin diwujudkan, maka akan ada warga negara minoritas (non muslim) yang berada di bawah posisi warga negara mayoritas (muslim). Hal ini justru memunculkan diskriminasi terhadap warga negara minoritas. Oleh karena itu, Gus Dur mengatakan bahwa NU tidak memperjuangkan Indonesia menjadi NII karena

\footnotetext{
${ }^{10}$ Lorens Bagus. Kamus Filsafat (Jakarta: PT. Gramedia Pustaka Utama, 2000), 154-156.

11 Abdurrahman Wahid, Islamku...., 102.

12 Abdurrahman Wahid, Islamku...., 91.
} 
kemajemukan yang tinggi dalam kehidupan bangsa Indonesia. Kenyataan seperti inilah yang sering dikacaukan oleh orang yang tidak mau mengerti bahwa mendirikan sebuah NII tidak wajib bagi kaum muslimin, tetapi mendirikan masyarakat yang berpegang kepada ajaran-ajaran Islam adalah suatu yan wajib. ${ }^{13}$

Negara Indonesia yang demokratis tidak menginginkan adanya warga negara yang minoritas, tertindas dan termarginalkan dalam kehidupan sosial kebangsaan. Semua warga negara harus memiliki persamaan hak, kewajiban dan peran sosial di masyarakat. Meskipun dalam tubuh kaum muslimin sendiri terdiri dari golongan ideologi tertentu yang berbeda, tetap harus menjunjung tinggi prinsip demokrasi yang anti kekerasan dalam menghadapi perbedaan. Kita harus memahami bahwa negara Indonesia adalah negara demokrasi yang tidak memaksakan keyakinan tertentu kepada orang lain dan tidak bertindak anarki terhadap pihak yang berbeda tersebut. Yang harus dijunjung tinggi adalah toleransi beragama terhadap perbedaan yang ada karena perbedaan itu adalah rahmat bagi umat.

Merupakan sikap keberagamaan yang harus diteladani dari Gus Dur ialah prinsip Islamku, Islam Anda, Islam Kita. Islam yang dipikirkan dan dialaminya adalah sesuatu yang khas, yang dapat disebutkan sebagai "Islamku", hingga karena watak perorangan seperti itu patut dipahami sebagai pengalaman pribadi, yang patut diketahui orang lain tanpa memiliki kekuatan pemaksa. Sementara "Islam Anda" lebih merupakan apresiasi dan refleksi Gus Dur terhadap tradisionalisme atau ritual keagamaan yang hidup dalam masyarakat. Dalam konteks ini, Gus Dur memberikan apresiasi terhadap kepercayaan dan tradisi keagamaan sebagai kebenaran yang dianut oleh komunitas masyarakat tertentu yang harus dihargai. "Islam Kita" lebih merupakan derivasi dari keprihatinan seseorang terhadap masa depan Islam yang didasarkan pada kepentingan bersama kaum Muslimin. ${ }^{14}$

Dari sini kita bisa mengambil makna pentingnya memahami Indonesia sebagai negara demokrasi, bukan negara Islam. Karena heterogenitas masyarakat di Indonesia, maka nilai-nilai etika Islam selaras dengan prinsip demokrasi yang mengutamakan kepentingan masyarakat, khususnya masyarakat minoritas tanpa melihat perbedaan SARA. Nilainilai etika yang diajarkan oleh Islam menyimpan kebaikan moral untuk kesejahteraan sosial sehingga relevan diterapkan dalam kehidupan

\footnotetext{
${ }^{13}$ Nur Khalik Ridwan, Gus Dur dan Negara Pancasila (Yogyakarta: Tanah Air, 2010),73-74.

14 Abdurrahman Wahid, Islamku...., xiv.
} 
bermasyarakat, berbangsa dan bernegara. Maka tidak salah Gus Dur mengutamakan etika sosial di negara demokrasi tanpa harus mendirikan negara Islam.

\section{Konsep Etika Islam Abdurrahman Wahid dan Relevansinya dalam Kehidupan Bermasyarakat, Berbangsa dan Bernegara}

Abdurrahman Wahid -yang lebih dikenal dengan panggilan Gus Durmenyatakan bahwa etika islam (islamic ethic) itu memiliki makna sepadan dengan akhlaq dan moral. Karena itu, ia sama sekali tidak membedakan pengunaan ketiga istilah tersebut, baik dalam ucapan maupun tulisan. Etika Islam ${ }^{15}$ memiliki makna yang sangat signifikan dalam mengantarkan kaum muslimin untuk mencapai cita-cita sosialnya sehingga Gus Dur mensyaratkan agar kaum muslimin menegakkan etika dalam kehidupan nyata. Ia menyatakan bahwa: “...... kaum muslimin memperjuangankan 'ideologi masyarakat' yang mereka ingini (kaum muslimin) melalui penegakkan etika islam bukannya ideologi islam." "16 Alasannya menurut Gus Dur bahwa Islam tidak berfungsi sebagai hukum Negara, melainkan sebagai jalan hidup masyarakat.

Penegakan etika islam dalam kehidupan berbangsa dan bernegara merupakan sebuah konsekuensi logis bagi umat islam karena Indonesia bukanlah Negara Islam melainkan Negara bangsa (demokrasi) yang terpisah secara formal dari agama. Hanya perlu disadari bahwa oleh Gus Dur sendiri pekerjaan itu terasa berat. Dalam hal ini Gus Dur mengatakan:

"Daripada memperjuangkan ajaran-ajaran islam menjadi hukum formal, lebih berat memperjuangkan moralitas bangsa. Tapi ini adalah konsekuensi terjauh dari pandangan kita untuk memisahkan agama dari Negara." 17

\footnotetext{
15 Menurut Hamzah Ya'kub, ada lima karakteristik etika islam: (1) Etika islam mengajarkan dan menuntut manusia kepada tingkah laku yang baik dan menjauhkan diri dari tingkah laku yang buruk. (2) Etika islam menetapkan bahwa yang menjadi sumber moral, ukuran baik buruknya perbuatan di dasarkan kepada ajaran Allah SWT, yaitu ajaran yang berasal dari AlQur'an dan al Hadis. (3) Etika islam bersifat universal dan komprehensif, dapat diterima oleh seluruh umat manusia di segala tempat dan waktu.(4) Ajaran-ajarannya bersifat ayang praktis dan tepat, cocok dengan fitrah (naluri) dan akal pikiran manusia, maka etika islam dapat dijadikan pedoman oleh seluruh manusia. (5) Etika islam mengatur dan mengarahkan fitrah manusia ke jenjang akhlak yang luhur dan meluruskan perbuatan manusia di bawah pancaran sinar petunjuk Allah SWT menuju keridhannya. Lihat Hamzah Ya'kub. Etika Islam: Pembinaan al Akhlaq al Karimah (suatu pengantar) (Bandung: CV.diponegoro, 1983), 14.

16 Abdurrahman Wahid, Islamku...., 115.

17 Abdurrahman Wahid, Islamku..., 73
} 
Etika islam (akhlaq) merupakan salah satu ajaran-ajaran islam yang bersifat universal. Nilai kebenarannya berlaku umum yaitu untuk kemaslahatan seluruh umat manusia di muka bumi ini. Sebagaimana nilai-nilai universal lainnya, nilai-nilai etika islam ini akan membawa kemajuan peradaban islam bilamana umat muslim mau menerapkanya dengan baik dalam kehidupan nyata. Hal ini dapat dilihat dalam fakta sejarah awal islam bahwasanya peradaban islam pernah mencapai era keemasannya (The Golden Age), yang oleh Arnold J. Toynbee disebut sebagai Oikumene peradaban islam. Untuk itu, pengembangan etika islam secara teoritis dan aplikasinya dalam kehidupan berbangsa dan bernegara perlu dilakukan. Hal itu akan menentukan masa depan peradaban islam dan tingkat kesejahteraan umat Islam.

Dalam hal ini, pengembangan etika ditempuh melalui penciptaan etika sosial baru. Gus Dur menyatakan:

"Dengan menampilkan universalisme baru dalam ajaran dan kosmopolitanisme baru dalam sikap hidup para pemeluknya, islam akan mampu memberikan perangkap sumberdaya manusia yang diperlukan oleh si miskin untuk memperbaiki nasib sendiri secara berarti dan mendasar, melalui penciptaan etika sosial baru yang penuh dengan semangat solidaritas sosial dan jiwa transformatif yang prihatin dengan nasib orang kecil." 18

Pengembangan etika islam merupakan agenda mendesak yang perlu dilakukan oleh umat muslim mengingat kondisi mereka masih berada dalam keterbelakangan peradaban dan deraan berbagai problem hampir di seluruh kawasan islam tanpa terkecuali. Gus Dur mengatakan:

“.... haruslah dikembangkan agenda universalisasi ajaran islam sehingga terasa kegunaan bagi umat manusia secara keseluruhan. Toleransi, keterbukaan sikap, kepedulian kepada unsur-unsur utama kemanusiaan, ke perihatinan yang penuh akan keterbelakangan kaum muslimin sendiri akan memunculkan tenaga luar bisasa untuk membuka belenggu kebodohan dan kemiskinan yang begitu kuat mencekam kehidupan mayoritas kaum muslimin dewasa ini." 19

Dalam konteks Indonesia, pengembangan ajaran islam sebagai etika sosial menurut Gus Dur penting dilakukan, selain karena permasalahanpermasalahan di atas karena masih adanya kaum muslimin yang menghendaki Islam sebagai alternatif hukum formal di indonesia. Penyebab dari kondisi tersebut menurut Gus Dur adalah karena mayoritas kaum muslimin masih berpikir sempit dan sangat eksklusif.

\footnotetext{
18 Abdurrahman Wahid, Islam Kosmopolitan; Nilai-Nilai Indonesiae Transformasi Kebudayaan (Jakarta: The Wahid Institute, 2007), 14.

19 Abdurrahman Wahid, Islam Kosmopolitan, 14
} 
Untuk itulah, Gus Dur mengusulkan pentingya pengembangan ajaran islam agar mampu mengambil bagian dalam kebangunan peradaban manusia yang akan muncul di masa pasca-industri nanti dan agar mereka kini tidak menjadi beban bagi kebangkitan umat manusia nanti. ${ }^{20}$

\section{Relevansi Etika Islam dalam Kehidupan Bermasyarakat, Berbangsa, dan Bernegara}

Etika Islam terkait dengan nilai-nilai yang disepakati oleh individu dalam masyarakat sehingga memiliki relevansi dalam kehidupan bermasyarakat, berbangsa, dan bernegara. Banyak bidangbidangkehidupan yang bisa direlevansikan dengan penerapan etika Islam atau istilah Gus Dur dengan etika sosial baru yang mengedepankan kesejahteraan sosial, diantaranya:

Pertama, bidang Agama. Etika Islam sangat relevan diterapkan dalam bidang agama mengingat banyak problematika terkait perbedaan cara pandang keberagamaan, apalagi kelompok mayoritas ideologi beragama di daerah tertentu mendominasi kelompok minoritas ideologi tertentu. Maka disinilah, nilai-nilai etika Islam harus dijunjung tinggi seperti toleransi beragama, tidak anarkis antar kelompok yang berbeda, dan tetap bersatu sebagai satu bangsa Indonesia.

Dalam hal ini, Gus Dur menyatakan bahwa meyakini sebuah kebenaran, tidak berarti hilangnya sikap menghormati pandangan orang lain ${ }^{21}$ dan keyakinan masing-masing tidak perlu diperbandingkan atau dipertentangkan karena perbedaan merupakan sebuah hal yang diakui islam, sedangkan yang dilarang adalah perpecahan dan keterpisahan. Menurut beliau, dengan tauhid, Islam menegakkan perbedaan pendapat dan keyakinan, dan jika perbedaan keyakinan dapat ditolerir dalam hal paling mendasar seperti dalam keimanan, tentunya sikap tenggang rasa lebih lagi diperkenankan dalam mengelola perbedaan pandangan politik dan ideologi. ${ }^{22}$

Kedua, bidang Politik dan Kepemimpinan. Etika Islam sangat relevan diterapkan dalam bidang politik dan kepemimpinan mengingat banyak problematika perbedaan ideologi politik dan kepemimpinan yang tidak pro rakyat banyak. Karena Indonesia sebagai negara demokrasi, maka ideologi politik yang berbeda merupakan hal yang wajar asalkan tetap menjunjung tinggi nilai-nilai etika Islam tanpa harus mementingkan labelisasi Islam. Dalam hal ini, Gus Dur mengatakan bahwa demokrasi

\footnotetext{
20 Abdurrahman Wahid, Islam Kosmopolitan, 13.

21 Abdurrahman Wahid, Islamku...., 236.

22 Abdurrahman Wahid, Islam Kosmopolitan, 6.
} 
mengajarkan kita untuk menghormati eksistensi parpol-parpol Islam, tetapi ini tidak berarti keharusan untuk mengikuti mereka. Selain itu, ia mengatakan bahwa kita harus memberikan tempat bagi perbedaan pendapat dan kemerdekaan berbicara, artinya adalah kebebasan menyatakan pikiran tanpa dikekang sama sekali.

Dalam hal kepemimpinan, ada dua problem yang bisa kita lihat yakni; masalah kepemimpinan yang tidak berorientasi pada kesejahteraan sosial seperti adanya tindak korupsi oleh pejabat pemerintahan, dan minimnya kesempatan yang dimiliki warga non muslim atau warga keturunan untuk masuk dalam pemerintahan padahal mereka juga bangsa Indonesia. Oleh karena itu, Gus Dur mengatakan bahwa seorang pemimpin harus memiliki keberanian moral untuk mengutamakan kepentingan rakyat, bukannya kepentingan sendiri atau pun kelompok. Selain itu, orientasi pembangunan negara untuk kepentingan warga masyarakat atau rakyat kebanyakan, harus lebih diutamakan dan bukannya pengembangan sumber daya manusia yang tinggi maupun penguasaan teknis yang memadai bagi modernisasi. Ia juga tidak menginginkan adanya negara Islam yang secara otomatis akan membuat warga Negara non-muslim berada di bawah kedudukan warga negara beragama islam.

Ketiga, bidang Hukum dan Hak Asasi Manusia. Etika Islam sangat relevan diterapkan dalam bidang hukum dan HAM mengingat banyak problematika terkait ketidakadilan memutuskan perkara dalam bidang hukum dan ketidakadilan meletakkan peran dan kedudukan manusia yang juga memiliki hak asasi yang harus dihargai. Dalam masalah ini, nilai-nilai etika Islam yang bisa diterapkan adalah menegakkan keadilan dan menghormati persamaan peran dan kedudukan manusia di mata hukum dan negara. Artinya, tidak boleh ada diskriminasi kelompok mayoritas yang memiliki kekuatan ekonomi dan kedudukan sosial terhadap kelompok minoritas yang lemah dalam hal ekonomi maupun kedudukan sosialnya.

Dalam bidang ini, Gus Dur mengatakan bahwa kita harus menegakkan keadilan dan tidak "menghukum" mereka yang tidak bersalah karenamenegakkan keadilan dan kemakmuran dalam ajaran agama islam disebut dengan istilah kesejahteraan yang harus menjadi orientasi. Konsep keadilan menurut Gus Dur pada prinsipnya berarti pemberdayaan kaum miskin atau lemah untuk memperbaiki nasib mereka sendiri dalam sejarah manusia yang terus mengalami perubahan sosial. $^{23}$

${ }_{23}$ Abdurrahman Wahid, Islam Kosmopolitan, 170. 
Adapun mengenai hak asasi manusia, Gus Dur selalu melawan anggapan atau penyebutan umat Budha, yang sebagian besar dianut oleh suku Tionghoa di negeri ini, sebagai "warga keturunan" sehingga harus memberi kerangka gerak yang memadai bagi umat Budha, yang merupakan salah satu asset (kekayaan) bangsa kita. Selain itu, Gus Dur mengutamakan memperjuangkan hak lelaki dan hak wanita menjadi semakin berimbang karena memang islam menilai seperti itu.

Keempat, bidang Sosial Budaya. Etika Islam sangat relevan diterapkan dalam bidang sosial budaya mengingat banyak problematika terkait masalah aksi umat Islam yang mengecam dan mencerca "goyang ngebor" Inul Daratista dan sebagian penyanyi dangdut lainnya yang baru merintis karir. Meskipun secara hukum Islam tidak sesuai, namun Gus Dur melihatnya dengan etika Islam yang mementingkan sisi sosial budaya. Nilai-nilai tersebut ialah melindungi hak asasi manusia "wong cilik" dari hegemoni elit keagamaan dan klaim atas moralitas kesenian yang agak represif. Padahal tujuannya mencari nafkah melalui seni menyanyi tanpa pantang menyerah. Dukungan Gus Dur bukan masalah sepakat atau tidak dan bukan melihat sisi formalnya yang dianggap sebagai bentuk penebaran nilai-nilai pornografi, tapi melihat dari segi substansi yang dilakukannya ketika dia mampu bersaing dengan penyanyi lain yang lama mendominasi, sekaligus melepaskan diri dari keterpurukan ekonomi. ${ }^{24}$

\section{Upaya Membumikan Etika Islam dalam Mengatasi Problematika Kelompok Minoritas di Indonesia}

Abdurrahman Wahid mengatakan bahwa agama itu kekuatan inspiratif, kekuatan moral sehingga harus membentuk etika dari masyarakat. Ketika membentuk etika masyarakat, maka agama itu sendiri merumuskan masa depan masyarakat itu seperti apa yang diingini, dengan menilai situasi masyarakat pada saat itu . ${ }^{25}$ Ada tiga strategi pengembangan etika Islam dalam upaya membumikan etika Islam sehingga diharapkan mampu mengatasi problematika kelompok minoritas di Indonesia, diantaranya:

\section{Transformasi Nilai-Nilai Etika Islam ke dalam Ranah Sosial}

Menurut Gus Dur bahwa dalam sejarah panjang, ajaran islam selalu menunjukkan keterkaitan antara urusan pribadi dan sosial. Untuk itu, Gus Dur menekankan supaya setiap ajaran dipahami secara baik. Hal ini barangkali dilatarbelakangi sebuah kenyataan bahwa umat islam memiliki pandangan yang parsial dalam memahami teks atau ajaran

\footnotetext{
24 Wasid. Gus Dur Sang Guru Bangsa (Yogyakarta: Interpena, 2010), 137-138.
}

25 Abdurrahman Wahid, Tabayun...., 159. 
agama yang sering dimaknai bersifat individual, tanpa mengaitkan dengan permasalahan sosial. Gus Dur mengatakan:

“.... dari semula, al-Qur'an telah memisahkan (lihat teks ayat) dua porsi keimanan kita (Rukun Iman dan Rukun Islam) dengan suatu jembatan yang berupa kesadaran yang mesti diputuskan statusnya. Keyakinan yang sangat bersifat pribadi tercantum dalam Rukun Iman, sedang dimensi sosialnya tercantum dalam Rukun Islam. Pada dimensi individu, ukuran keimanan bersifat sangat pribadi dan merupakan urusan seseorang berhubungan dengan Allah sendiri. Sedang pada dimensi sosialnya, Rukun Islam syahadat yang mestinya sangat pribadi yaitu iman kepada Allah, berwawasan sosial karena pengucapannya sering harus dilakukan di muka orang banyak dan dipakai dalam persaksian dan sumpah. Begitu juga tentang Rukun Islam yang lain. Shalat, apalagi berjamaah, berfungsi mencegah perbuatan keji dan munkar, yang berarti mengandung orientasi menjaga keterlibatan masyarakat. Sementara zakat telah jelas sebagai ibadah sosial dan ibadah haji adalah saat berkumpulnya kaum muslimin dari segala penjuru dengan berbaju ihram yang sama tanpa memandang tinggi dan rendah". ${ }^{26}$

Melihat realitas pemahaman yang demikian ini, Gus Dur mengajukan sebuah gagasan untuk menjebatani kesenjangan antara 'rukun iman' yang bersifat personal dengan 'rukun islam' yang bersifat sosial melalui gagasan perlunya 'rukun sosial' yaitu perhatian yang cukup terhadap kaum lemah.

"Persoalannya kini adalah bagaimana dimensi pribadi ini bisa diterjemahkan secara sosial, sebab di dalam iman ternyata adalah mungkin untuk menjadi mu'min yang baik dan sekaligus menjadi makhluk a-sosial. Sebaliknya bisa terbentuk pula sikap hidup yang begitu sosial tetapi tanpa keimanan. Usaha menjembatani kedua bentuk keberagamaan yang ekstrem ini adalah sebuah keharusan yang ditunjuk oleh ayat tadi. Ayat ini menghubungkan Rukun Iman dan Rukun Islam dengan "rukun sosial", yaitu perhatian yang cukup terhadap dana untuk membela kaum lemah." 27

Bila seorang muslim mampu menterjemahkan aspek keimanan yang bersifat pribadi ke dalam ranah sosial, maka orang tersebut menurut Gus Dur digolongkan sebagai 'muslim yang baik', yaitu seorang yang telah memenuhi lima syarat.

“.... jika seorang muslim telah melaksanakan lima syarat sebagaimana dinyatakan al Qur'an maka dia dapat dianggap sebagai "muslim yang baik". Lima syarat tersebut yaitu menerima prinsip-prinsip keimanan, menjalankan ajaran (rukun) islam secara utuh, menolong mereka yang

\footnotetext{
26 Abdurrahman Wahid. Menggerakkean Tradisi (Yogyakarta: LkiS, 2010), 138.

27 Abdurrahman Wahid. Menggerakean Tradisi, 140.
} 
memerlukan pertolongan (sanak-saudara, anak yatim, kaum msikin dan sebagainya), menegakkan profesionalisme dan bersikap sabar ketika menghadapi cobaan dan kesusahan."28

\section{Implementasi Nilai-nilai ETIKA ISLAM dalam Mengatasi Problematika Kelompok Minoritas}

Selama ini, nilai-nilai etika Islam belum menjawab berbagai persoalan sosial di Indonesia termasuk masalah yang mengorbankan kelompok minoritas. Padahal etika Islam mencakup etika terapan yang juga berusaha mewujudkan kesejahteraan sosial. Untuk itu, merupakan hal yang urgen mewacanakan etika Islam di ruang publik mengingat penyebab utama konflik dan kontroversi tidak sehat adalah tidak adanya etika yang dijunjung tinggi. Selain itu, perlu implmentasi yang kontinyu khususnya generasi muda tentang nilai-nilai etika Islam dalam berbagai bidang kehidupan untuk menghadapi tantangan modernitas. Gus Dur menggunakan istilah etika terapan dengan etika sosial yang berpedoman pada sumber ajaran Islam, baik Qur'an dan hadis, kaidah ushul fiqh, maupun ajaran tasawuf. Diantara nilai-nilai etika sosial itu ialah:

Pertama, nilai toleransi (menghormati perbedaan). Nilai etika islam ini merupakan salah satu etika keutamaan yang sangat ditekankan oleh Gus Dur,sebab perbedaan itu merupakan realitas kehidupan sosial yang bersifat pasti (sunnatullah) sebagai bagian dari anugerah Tuhan yang harus disyukuri setiap manusia. Gus Dur memaparkan adagium: "Perbedaan pandangan di kalangan para pemimpin adalah rahmat bagi umat". Perbedaan dalam segala hal adalah hak asasi bagi setiap umat manusia yang harus dihormati, diantaranya menghormati dalam ideologi politik, pilihan partai politik, mengemukakan pendapat dan berpikir, dan keyakinan dan ideologi beragama.

Dengan implementasi nilai etika ini, diharapkan masyarakat yang berbeda-beda dalam berbagai bidang apapun tetap saling menghormati dan tidak memaksakan kehendak kepada orang lain, mengingat kemajemukan masyarakat Indonesia. Kelompok minoritas merasa memiliki kebebasan berpendapat, berideologi, dan berpikir tanpa rasa takut meski berbeda sehingga Indonesia tetap bercirikan Bhinneka Tunggal Ika "Berbeda tapi tetap satu."

Kedua, nilai cinta perdamaian, bukan kekerasan. Nilai etika islam ini bertujuan untuk mewujudkan kehidupan yang penuh keharmonisan di tengah-tengah realitas kehidupan yang begitu plural. Dalam menghadapi kondisi seperti itu, Islam menganjurkan untuk mengedepankan

28 Abdurrahman Wahid, Islamku...., 4. 
perundingan ketika terjadi perselisihan karena kesediaan untuk berunding menurut Gus Dur merupakan solusi terbaik. Ia menggunakan adagium "sebaik-baik persoalan adalah yang berada di tengah-tengah."

Di samping sikap kesediaan berunding, Gus Dur melarang kepada umat muslim melakukan tindak kekerasan kepada siapapun karena itu merusak tatanan sosial. Gus Dur mengungkapkan bahwa orang Islam diperkenankan mengunakan kekerasan hanya jika diusir dari kediaman mereka. Selain alasan tersebut, tidak diperkenankan menggunakan kekerasan kepada siapapun, walaupun atas keunggulan pandangan islam. $^{29}$

Dengan implementasi nilai etika ini, diharapkan kelompok minoritas merasa aman meski berbeda dan menuai perselisihan karena segala masalah bisa diselesaikan dengan cara damai (berunding). Artinya, tidak ada kekerasan (anarkisme dan arogan) dalam menyelesaikan permasalahan bersama dalam kehidupan sosial. Jika ini dilakukan, maka selaras dengan prinsip demokrasi yang mengedepankan kemerdekaan berbicara, berpendapat, dan berpikir.

Ketiga, nilai menegakkan keadilan. Nilai etika Islam ini harus ditegakkan, baik dalam bidang hukum maupun bidang hak asasi manusia. Nilai ini perlu diimplementasikan dalam kehidupan bermasyarakat, berbangsa, dan bernegara agar kelompok minoritas tidak merasa tertindas karena ketidakadilan yang sering menjerumuskan mereka pada justifikasi jeratan hukum, padahal kenyataannya mereka tidak bersalah. Gus Dur memaknai konsep keadilan yang berarti pemberdayaan kaum miskin atau lemah untuk memperbaiki nasib mereka sendiri dalam sejarah manusia yang terus mengalami perubahan sosial.

Keempat, nilai persamaan kedudukan manusia di mata hukum dan Negara. Bentuk implementasi nilai etika Islam ini ialah tidak menganggap kelompok minoritas seperti etnis tionghoa sebagai orang-orang asing di negara Indonesia, juga bagi mantan Napol dan Tapol PKI tetap sama kedudukannya di mata hukum dan negara karena sebagian mereka justru tidak mengetahui dan tidak menganut paham komunis. Dengan implementasi ini diharapkan kelompok minoritas tidak merasa lebih rendah dan diberi ruang gerak bagi pengembangan diri mereka di ruang publik.Bentuk implementasi lainnya ialah meluruskan bahwa hak lelaki dan wanita di muka hukum itu sama yang dijamin oleh UUD.

Kelima, nilai kepedulian social. Prinsip etika ini adalah menaruh kepedulian kepada masyarakat lemah (kelompok minoritas) sebagai salah

${ }^{29}$ Abdurrahman Wahid, Islamku...., 365. 
satu bentuk turut tanggung jawab moral terhadap permasalahan mereka. Sikap ini menurut Gus Dur penting sehingga perlu diutamakan. Bentuk implementasi nilai etika ini ialah; (a) mengutamakan kepentingan warga masyarakat kebanyakan untuk pembangunan negara sesuai proses modernisasi, (2) berusaha menciptakan kesejahteraan lahir bersama, (c) memperjuangkan nasib rakyat kecil serta kepentingan orang banyak, (d) memberikan perlindungan kepada yang lemah, dan (e) memberdayakan kaum miskin atau lemah untuk memperbaiki nasib sendiri.

\section{Orientasi Pengembangan Etika Islam harus Kearah Kesejahteraan Umat}

Orientasi pengembangan etika islam menurut pandangan Gus Dur adalah terwujudnya kesejahteraan atau dengan bahasa fiqh-nya "almaslahah al-âmmab" (kesejahteraan umum). Orientasi paham keislaman sebenarnya adalah kepentingan orang kecil dalam hampir seluruh persoalan. Lihat saja kata "maslahah 'âmmah", yang berarti kesejahteraan umum. Inilah sebenarnya yang menjadi objek dari segala macam tindakan yang seharusnya diambil pemerintah. ${ }^{30}$

Dalam bahasa pembukaan UUD 1945, kata kesejahteraan tersebut dirumuskan dengan ungkapan lain, yaitu dengan istilah "masyarakat adil dan makmur". Itulah tujuan dari berdirinya sebuah Negara Kesatuan Republik Indonesia (NKRI) dalam siklus berikut: hak setiap bangsa untuk memperoleh kemerdekaan, guna mewujudkan perdamaian dunia yang abadi dan meningkatkan kecerdasan bangsa, guna mencapai tujuan masyarakat adil dan makmur. Dengan menanggapnya sebagai tujuan bernegara, UUD 1945 jelas-jelas menempatkan kesejahteraan/keadilankemakmuran sebagai sesuatu yang esensial bagi kehidupan kita.

Menarik sekali ungkapan fiqh 'kebijakan dan tindakan seorang pemimpin atas rakyat yang dipimpin, harus terkait langsung dengan kesejahteraan mereka (tasarruf alimâm 'alâ alra'iyyah manûtun bi al-maslaḥah). Karena itu, kepentingan rakyat adalah ukuran satu-satunya dalam islam bagi penyelenggaraan pemerintah yang baik.

\section{Kesimpulan}

Untuk memahami ajaran Islam sebagai sumber etik, perlu mengedepankan kesejahteraan sosial (al-maslabah al-âmmab) dengan implementasi nilai-nilai ajaran agama dan transformasi nilai-nilai Islam ke dalam ranah sosial. Abdurrahman Wahid bisa dikatakan salah satu pionir

30 Abdurrahman Wahid, Gus Dur Menjawab Kegelisahan Rakyat (Jakarta: Kompas, 2007), 25. 
bagi perwujudan nilai-nilai etika Islam, meski diyakini bersifat kontraproduktif terhadap upaya menegakkan prinsip-prinsip demokrasi, HAM dan pluralisme di kawasan yang majemuk ini. Beliau memiliki pemikiran transformatif dalam memaknai ajaran islam terutama dalam hal etika sosial.

Menurut penulis, kelompok mayoritas ialah kelompok yang mendominasi (kuat) dan kelompok minoritas ialah kelompok yang terdominasi (lemah). Namun, sebenarnya dalam kehidupan demokrasi dua kutub kelompok ini tidak perlu ada karena demokrasi menjunjung tinggi persamaan hak, peran, dan kedudukan sebagai warga masyarakat. Berdasarkan analisis penulis, diantara faktor yang mendorong adanya kelompok mayoritas yang mendominasi kelompok minoritas sehingga merasa tertindas dan termarjinalkan ialah: (a) belum memahami bahwa Indonesia merupakan negara demokrasi, bukan negara Islam, (b) belum memahami esensi nilai-nilai ajaran Islam yang juga berorientasi pada perwujudan kesejahteraan sosial, dan (c) belum memahami pentingnya kesadaran membumikan etika Islam yang ditansformasikan ke dalam ranah sosial.

Ada beberapa bentuk dominasi terhadap kelompok minoritas di Indonesia, yakni kekerasan yang dialami kelompok minoritas di Sampang yang berpaham Syi'ah, menomorduakan kelompok minoritas warga Tionghoa yang dianggap warga keturunan sehingga seringkali tidak diberi ruang gerak di bidang publik khususnya pemerintahan, kecaman terhadap kelompok minoritas umat Islam seperti Ulil Abshar Abdalla karena perbedaan ideologi pemikiran Islam melalui liberalisme Islam, memusuhi dan membatasi ruang gerak orang-orang mantan Napol dan Tapol PKI yang kebanyakan bukan orang yang benar-benar memahami ideologi komunis, kecaman terhadap aksi goyang ngebor Inul Daratista yang dipandang berbau pornografi.

Penegakan etika Islam dalam kehidupan berbangsa dan bernegara merupakan sebuah konsekuensi logis bagi umat islam karena Indonesia bukanlah Negara Islam melainkan Negara bangsa (demokrasi) yang terpisah secara formal dari agama. Hanya perlu disadari bahwa oleh Gus Dur sendiri pekerjaan itu terasa berat. Namun, pengembangan etika perlu diupayakan melalui penciptaan etika sosial baru yang penuh dengan semangat solidaritas sosial dan jiwa transformatif yang prihatin dengan nasib orang kecil. 


\section{Daftar Pustaka}

Bagus, Lorens. Kamus Filsafat. Jakarta: PT. Gramedia Pustaka Utama. 2000.

Hilmy, Masdar. Islam Profetik; Substansialisasi Nilai-nilai Agama dalam Ruang Publik.Yogyakarta: Kanisius, 2008.

Muthahhari, Murtadha. Masyarakat dan Sejarah. Bandung: Mizan, 1985.

Muzadi, A. Hasyim dan Benediktus Bosu. Menuju Indonesia Baru; Strategi Pemberantasan Tindak Pidana Korupsi. Malang: Bayumedia Publishing. 2004.

Ridwan, Nur Khalik. Gus Dur dan Negara Pancasila. Yogyakarta: Tanah Air, 2010.

Wahid, Abdurrahman. Gus Dur Menjawab Kegelisahan Rakyat. Jakarta: Kompas. 2007.

Islam Kosmopolitan; Nilai-Nilai Indonesia dan Transformasi Kebudayaan. Jakarta: The Wahid Institute, 2007. Institute, 2006. . Islamku, Islam Anda, Islam Kita. Jakarta: Wahid . Menggerakkan Tradisi. Yogyakarta: LKiS, 2010.

Wasid. Gus Dur Sang Guru Bangsa. Yogyakarta: Interpena, 2010.

Ya'kub, Hamzah. Etika Islam: Pembinaan al Akhlaq al Karimah (suatu pengantar). Bandung: CV.diponegoro, 1983. 